\title{
Impact of the biocontrol beetle, Cassida rubiginosa, on the secondary weed target, marsh thistle (Cirsium palustre)
}

\author{
Dilani Hettiarachchi ${ }^{1}$, Michael Cripps ${ }^{2, *}$, Sarah Jackman ${ }^{2}$, Chikako van Koten ${ }^{2}$, Jon \\ Sullivan ${ }^{3}$, and Michael Rostás ${ }^{1}$ \\ ${ }^{1}$ Bio-Protection Research Centre, Lincoln University, Lincoln, New Zealand. \\ ${ }^{2}$ AgResearch, Lincoln Research Centre, Lincoln, New Zealand. \\ ${ }^{3}$ Faculty of Agriculture and Life Science, Lincoln University, Lincoln, New Zealand. \\ *Corresponding author: mike.cripps@agresearch.co.nz
}

\begin{abstract}
The folivorous beetle Cassida rubiginosa was introduced to New Zealand to control the weed, Californian thistle (Cirsium arvense). Although Californian thistle is the primary host, many other thistles are accepted hosts. The objective of this study was to test if the beetle can reduce the fitness of marsh thistle (Cirsium palustre). A potted plant experiment was established with four treatments (0, 50, 100, and 200 larvae/plant). Plant growth (width, height, and number of branches) and reproductive performance (number of flowers, seeds, seed weight and percent germination) parameters were measured. No significant differences were found for any of the measured parameters, except percent germination. Higher larval densities (100 and 200) resulted in approximately 10\% less germination compared with lower densities ( 0 and 50). Under these experimental conditions, C. rubiginosa had minimal impact on the performance of marsh thistle. For the beetle to have an impact, it would likely need to attack smaller, non-bolting rosettes, or be combined with additional stressors that might be encountered in a natural field population.
\end{abstract}

Keywords green thistle beetle, seed viability, alternative host, Cirsium.

\section{INTRODUCTION}

Herbivorous arthropods released as weed biocontrol agents need to be sufficiently hostspecific to ensure safety to non-target plants. The normal practice is to release the most specialised agents, typically those that are monophagous, or restricted to a defined group of host plants closely related to the target weed. Historically, the cases of classical biocontrol agents released against thistle weeds were no exception to this practice, with the most specialised agents selected and released. In New Zealand, eight biocontrol agents were released from 1973 to 1998 against three thistle weeds: Californian thistle (Cirsium arvense), Scotch thistle (Cirsium vulgare), and nodding thistle (Carduus nutans) (Winston et al. 2014). These historical releases made use of 'transfer projects' whereby the same agents previously released in temperate North America were released in New Zealand (Fowler et al. 2010). The most host-specific agents were released in North America to minimise the potential for non-target attack to native thistle species occurring there (Schröder 1980). The transfer projects were an economical way to safely release biocontrol agents in New Zealand, but not necessarily the best for releasing the most effective agents (Cripps et al. 2011).

Thistles, in the broad sense, belong to a welldefined taxonomic group (monophyletic tribe), the Cardueae, of which there are no native representatives in New Zealand (Webb et al. 1988). The absence of native Cardueae species in New Zealand, and only a few introduced 
species of economic value within the tribe (e.g. artichoke and safflower), provides a rare opportunity to release oligophagous biocontrol agents specialised at the tribal level. Thus, a new approach, considering the absence of native thistles in New Zealand, resulted in the release of the oligophagous beetle, Cassida rubiginosa, in 2007 . The primary target of this biocontrol agent is Californian thistle, although the potential for control of other thistle weeds, which could be considered secondary targets, has been recognised (Bourdôt et al. 2007). At least 63 thistle weed species have been introduced into New Zealand, of which nine are currently agricultural weeds of economic significance, and the remaining species are considered 'sleeper weeds' with potential to become problematic (Cripps et al. 2013).

Several studies have demonstrated that the beetle can control its primary host, Californian thistle (Ang et al. 1995; Bacher \& Schwab 2000; Cripps et al. 2010), but little is known about its potential to control other thistle weeds. The ability for Cassida rubiginosa to control Californian thistle is due, at least in part, to the thistle's unique biology, being a perennial reproducing by seed and by creeping lateral roots. All other thistle weeds reproduce solely by seed. In established populations of Californian thistle, reproduction is primarily by vegetative means, with little recruitment from seed, unless there is soil disturbance (e.g. from cattle pugging, or tillage) (Edwards et al. 2000). Furthermore, the creeping roots are ephemeral, lasting no longer than one year, and the annual formation of new root biomass is directly related to the photosynthetic opportunity of the plant over the growing season (Bourdôt et al. 1998). Thus, defoliation in one growing season can reduce the production of root biomass, and cause subsequent shoot population decline.

With regard to other Cardueae species in New Zealand, adult Cassida rubiginosa have been observed to feed and oviposit on field populations of nodding thistle, Scotch thistle, winged thistle (Carduus tenuiflorus), marsh thistle (Cirsium palustre), and artichoke (Cynara scolymus) (unpublished data). Utilisation of these plants was predicted by pre-release choice and no-choice host testing (Paynter et al. 2015); however, the potential impact on individual plant, or population performance, is uncertain. As an initial step towards understanding the potential impact of Cassida rubiginosa on other thistle weeds, marsh thistle was selected as a test species, since it is closely related (congeneric) to Californian thistle, and the survival of the beetle is equivalent on this species (Cripps et al. 2016). The objective of this study was to test the impact of different densities of Cassida rubiginosa larval feeding on growth and reproductive performance of marsh thistle.

\section{MATERIALS AND METHODS}

\section{Study system}

The experiment was conducted at AgResearch

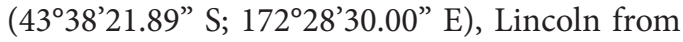
13 September 2016 to 1 January 2017. Marsh thistle rosettes were excavated from three sites along the Kumara - Inchbonnie Road, Westland (Site 1-42 $39^{\prime} 42.10^{\prime \prime}$ S 171 $25^{\circ} 57.18^{\prime \prime}$

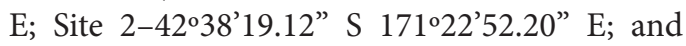
Site 3-42'38'58.72" S $171^{\circ} 18^{\prime} 38.06^{\prime \prime}$ E) on 29 August 2016. Care was taken to collect plants of similar size (rosette diameter) and same habitat (roadside). Due to the facultative biennial nature of the plant (Falińska 1997), overwintered rosettes of sufficient size (i.e. $>40 \mathrm{~cm}$ diameter) were collected to ensure that they would able to flower and produce seeds (Falińska 1997). The plants were transplanted into 12-litre pots containing a standard potting mix (54\% aged bark, $45 \%$ sand, $1 \%$ nutrients, by weight) with added nutrients as Osmocote ${ }^{\varpi}$ 17-11-10 (N-P-K), lime, superphosphate, sulphate of potash and calcium nitrate. The experiment was set up as a randomised block design with five replicate blocks, and four larval density treatments: 0, 50, 100, or 200 larvae per plant. When larvae were applied, there were no significant differences in the width $(\mathrm{P}=0.291)$ or height $(\mathrm{P}=0.407)$ of plants assigned to the four treatments. The potted plants were spaced $40 \mathrm{~cm}$ apart in the blocks to 
ensure no leaves overlapped. The plants were watered three times per day for 5 minutes with an automatic irrigation system that delivered water directly to the soil of the pot via a Dutch spike.

Adult beetles were collected from a population of Californian thistle near Masterton (Wairarapa) on 20 October 2016. The insects were reared under laboratory condition in 2-litre ventilated plastic boxes and fed with Cirsium arvense clippings. Eggs laid between 21-25 October were kept at $20^{\circ} \mathrm{C}$ in Petri dishes lined with moist filter papers until larvae hatched. On 1-2 November 2016, naïve first instar larvae were applied to the appropriate treatment plants in the experiment, which matches the time period when larvae would typically begin to hatch in the field (Cripps 2013). Flowering began on 8 November and by 19 December 2016, all plants in the experiments were flowering. Throughout the flowering period, honeybees and bumblebees were observed pollinating the flowers. To estimate seed production, 20 flower heads (assumed to be pollinated) from each plant were covered with polythene mesh bags on 19 December. After two weeks, the seeds were collected, air dried and stored at $5^{\circ} \mathrm{C}$ for 12 months. On 25 December, visual estimates of percent leaf tissue removed from each plant (\% herbivory) were recorded. At the end of the experiment on 1 January 2017, plant growth (mature plant height, width, and number of branches) and reproductive performance (number of flowers, number of seeds, seed weight and germination rate) parameters were measured.

Seed germination was tested from a random subset of 100 seeds per plant. The seeds were weighed and placed into Petri dishes $(9 \mathrm{~cm}$ diameter) with filter paper moistened with $2 \mathrm{~mL}$ of distilled water. The dishes were then placed in an incubator at $25^{\circ} \mathrm{C}$ (van Leeuwen 1981) and 8:16 hour dark and light conditions (Pons 1984; Huarte 2005). Every third day, $1 \mathrm{~mL}$ of distilled water was added to the Petri dishes to prevent desiccation. Seeds were removed as they germinated over a 21-day period.

\section{Data analysis}

The percent feeding damage was compared between the treatments using one-way analysis of variance (ANOVA). Since there was no damage on control plants (0\%) the ANOVA was applied only to the three beetle treatment groups (50, 100 and 200 larvae/plant groups). Pair-wise comparisons were made between each of beetle treatment groups, and then for each beetle treatment against the zero control group using one-sample t-tests. The percent seed germination data was analysed using a generalised linear model assuming a binomial distribution through a logit link function. All other variables were analysed with ANOVA followed by Fisher's protected least significant difference (LSD) test to compare among the four treatment means. The data were analysed using Minitab version 16 and Genstat version 16.

\section{RESULTS}

The percent feeding damage was significantly different among the four beetle treatments $(\mathrm{P}<0.001)$, and there was no feeding observed on the control plants confirming that larvae were confined to their assigned treatment plants (Table 1).

Herbivore treatment density had no significant effect on any of the measured plant traits (mature plant height $\mathrm{P}=0.407$; width $\mathrm{P}=0.577$; number of branches $\mathrm{P}=0.241$; number of flowers $\mathrm{P}=0.688$; number of seeds $\mathrm{P}=0.642$; seed weight $\mathrm{P}=0.450$ ), except for seed germination $(\mathrm{P}<0.001)$. Seeds from plants treated with 200 and 100 larvae showed significantly reduced germination rates compared with seeds from plants subjected to 0 and 50 larvae (Table 1). Compared to control plants without herbivory, the germination rate was reduced by $8 \%$ (100 larval treatment) and $10 \%$ (200 larval treatment). 
Table 1 Mean ( \pm standard error) herbivory, reproductive and growth parameters of marsh thistle (Cirsium palustre) after treatment with 0, 50, 100, or 200 larvae per plant of the folivorous beetle, Cassida rubiginosa. Treatment means sharing a common letter do not differ at the $5 \%$ significance level.

\begin{tabular}{llccc}
\hline Parameter & \multicolumn{4}{c}{ Treatment (larvae per plant) } \\
\hline $\begin{array}{l}c \\
\text { Herbivory }(\%)\end{array}$ & $0^{\mathrm{d}}$ & 50 & 100 & 200 \\
Reproductive & & $35 \pm 1.0^{\mathrm{c}}$ & $49 \pm 2.7^{\mathrm{b}}$ & $63 \pm 1.4^{\mathrm{a}}$ \\
Germination (\%) & $84 \pm 2.30^{\mathrm{a}}$ & $84 \pm 2.18^{\mathrm{a}}$ & $76 \pm 2.89^{\mathrm{b}}$ & $74 \pm 3.87^{\mathrm{b}}$ \\
Seed weight (g/100) & $0.172 \pm 0.01^{\mathrm{a}}$ & $0.165 \pm 0.01^{\mathrm{a}}$ & $0.154 \pm 0.003^{\mathrm{a}}$ & $0.160 \pm 0.006^{\mathrm{a}}$ \\
Number of seeds ${ }^{2}$ & $424 \pm 56.7^{\mathrm{a}}$ & $458 \pm 28.6^{\mathrm{a}}$ & $382 \pm 55.4^{\mathrm{a}}$ & $438 \pm 14.7^{\mathrm{a}}$ \\
Flowers/plant & $192 \pm 61.5^{\mathrm{a}}$ & $258 \pm 40.3^{\mathrm{a}}$ & $251 \pm 41.7^{\mathrm{a}}$ & $195 \pm 52.7^{\mathrm{a}}$ \\
Growth & & & \\
Height (cm) & $174 \pm 15.2^{\mathrm{a}}$ & $147 \pm 5.68^{\mathrm{a}}$ & $146 \pm 24.1^{\mathrm{a}}$ & $137 \pm 11.5^{\mathrm{a}}$ \\
Width (cm) & $55 \pm 0.73^{\mathrm{a}}$ & $53 \pm 0.92^{\mathrm{a}}$ & $54 \pm 0.89^{\mathrm{a}}$ & $53 \pm 2.04^{\mathrm{a}}$ \\
Number of branches & $17 \pm 3.65^{\mathrm{a}}$ & $10 \pm 0.5^{\mathrm{a}}$ & $14 \pm 3.06^{\mathrm{a}}$ & $13 \pm 1.46^{\mathrm{a}}$ \\
\hline
\end{tabular}

${ }^{1}$ Leaf tissue removed by larvae from each plant

${ }^{2}$ The mean number of seeds is based on the total from 20 seedheads per plant.

\section{DISCUSSION}

This study assessed the impact of the oligophagous beetle Cassida rubiginosa on marsh thistle, a secondary weed target closely related to the biocontrol agent's primary target, Californian thistle. Even at the highest treatment density of 200 larvae per plant, C. rubiginosa did not cause sufficient damage to affect the growth or seed production of individual marsh thistle plants. The only detected effect was on seed germination rates, which were significantly reduced in plants that had experienced herbivory from 100 or 200 beetle larvae. However, since the number of seeds and weight of seeds were equivalent between beetle treatments, it is unclear why germination rates might have been different. Furthermore, even though this was a significant effect, it was only $10 \%$ different to the control plants, and thus unlikely to scale to population level declines of the weed.

The results of our study suggest that once sufficient rosette size is obtained to initiate bolting, it is unlikely that folivory alone will be able to reduce seed production. A similar result was reported with nodding thistle rosettes, where larval feeding by C. rubiginosa caused $23 \%$ defoliation, but had no effect on plant growth or seed production (Cartwright \& Kok 1990). Nevertheless, while even a high level of folivory (e.g. 50 to $60 \%$, as imposed here experimentally) might not reduce the performance of a large rosette or bolting plant, it could affect smaller plant size classes. Marsh thistle is a facultative biennial: some individuals grow as a strict biennial, and reproduce in their second year, following a vernalisation period as a vegetative rosette; but many individuals remain in the vegetative state for three to five years before obtaining sufficient size to bolt and produce seeds (Ballegaard \& Warncke 1985; Falińska 1997). The probability of transitioning to the reproductive stage increases sharply for rosettes over $20 \mathrm{~cm}$ in diameter and, at $40 \mathrm{~cm}$, bolting is a near certainty.

In our study, large rosettes ( $>40 \mathrm{~cm}$ diameter) were used in order to ensure that any impact of 
folivory on seed production could be measured. If smaller rosettes had been used, with lower probability of bolting, folivory by C. rubiginosa might have had an effect. Ultimately, C. rubiginosa will need to reduce seed output in order to cause population level declines of marsh thistle, or other secondary thistle weeds. This could be achieved by reducing the survivorship of rosettes, delaying the transition to the reproductive stage, or reducing the size of reproductive plants, since plants that bolt from smaller rosettes tend to produce less seed (Falińska 1997). In the case of nodding thistle, the rosette-feeding weevil (Trichosirocalus horridus), was shown to contribute more to population decline than seed feeders since it reduced the growth and survival of individual plants in the population (Shea et al. 2006). In contrast, nodding thistle seedfeeders did not reduce the survival or vigour of individual plants, and therefore high rates of seed consumption (at least 70\%) were necessary to cause significant population declines (Shea \& Kelly 1998).

Biocontrol agents are often more effective when combined with other stress factors, such as complementary biocontrol agents, interspecific plant competition, and resource limitation (e.g. drought or nutrient stress) (Sheppard 1996). In the current study, marsh thistle plants were grown in large pots, free from competition, and with ample nutrients and water, enhancing the potential for the plants to compensate for the herbivore damage (Hawkes \& Sullivan 2001). Under field conditions, their growth would be constrained by competition and environmental factors (Falińska 1997). Under these conditions, folivory could have an impact on the weed. The extent to which C. rubiginosa might contribute to the control of secondary target weeds, will depend not only on the severity of attack, but on the phenological stages attacked, with younger or smaller stages more likely to be affected. Further studies assessing the impact of this biocontrol agent on different phenological stages of annual and facultative biennial thistle weeds would be of value.

\section{ACKNOWLEDGEMENTS}

This study was funded by the New Zealand Ministry of Business, Innovation, and Employment through AgResearch core funding of pasture weed research. We thank Prof. John Hampton, Bio-Protection Research Centre, for advice concerning seed germination techniques. We thank Josefina Narciso, Bio-Protection Research Centre for technical assistance.

\section{REFERENCES}

Ang BN, Kok LT, Holtzman GI, Wolf DD 1995. Canada thistle (Cirsium arvense (L.) Scop.) response to density of Cassida rubiginosa Müller (Coleoptera: Chrysomelidae) and plant competition. Biological Control 5: 3138.

Bacher S, Schwab F 2000. Effect of herbivore density, timing of attack and plant community on performance of creeping thistle Cirsium arvense (L.) Scop. (Asteraceae). Biocontrol Science and Technology 10: 343-352.

Ballegaard TK, Warncke E 1985. The age distribution of a Cirsium palustre population in a spring area in Jutland, Denmark. Ecography 8: 59-62.

Bourdôt GW, Fowler SV, Edwards GR, Kriticos DJ, Kean JM, Rahman A, Parsons AJ 2007. Pastoral weeds in New Zealand: status and potential solutions. New Zealand Journal of Agricultural Research 50: 139-161.

Bourdôt GW, Leathwick DM, Hurrell GA, Saville DJ 1998. Relationship between aerial shoot and root biomass in Californian thistle. Proceedings of the New Zealand Plant Protection Society 51: 28-32.

Cartwright B, Kok LT 1990. Feeding by Cassida rubiginosa (Coleoptera: Chrysomelidae) and the effects of defoliation on growth of musk thistles. Journal of Entomological Science 25: 538-547.

Cripps MG 2013. Observations on the thistlefeeding tortoise beetle, Cassida rubiginosa (Coleoptera: Chrysomelidae). The Weta 45: 5-13.

Cripps MG, Bourdôt GW, Fowler SV 2013. Sleeper thistles in New Zealand: status and 
biocontrol potential. New Zealand Plant Protection 66: 99-104.

Cripps MG, Edwards GR, Bourdot GW, Saville DJ, Hinz HL, Fowler SV 2010. Effects of pasture competition and specialist herbivory on the performance of Cirsium arvense. Biocontrol Science and Technology 20: 641-656.

Cripps MG, Gassmann A, Fowler SV, Bourdôt GW, McClay AS, Edwards GR 2011. Classical biological control of Cirsium arvense: Lessons from the past. Biological Control 57: 165-174.

Cripps MG, Jackman SD, Roquet C, van Koten C, Rostás M, Bourdôt GW, Susanna A 2016. Evolution of Specialization of Cassida rubiginosa on Cirsium arvense (Compositae, Cardueae). Frontiers in Plant Science 7: 1261.

Edwards GR, Bourdôt GW, Crawley MJ 2000. Influence of herbivory, competition and soil fertility on the abundance of Cirsium arvense in acid grassland. Journal of Applied Ecology 37: 321-334.

Falińska K 1997. Life history variation in Cirsium palustre and its consequences for the population demography in vegetation succession. Acta Societatis Botanicorum Poloniae 66: 207-220.

Fowler SV, Paynter Q, Hayes L, Dodd S, Groeteman R 2010. Biocontrol of weeds in New Zealand: an overview of nearly 85 years. In: Zydenbos SM ed. Seventeenth Australasian Weeds Conference. Christchurch, New Zealand, New Zealand Plant Protection Society. Pp. 211-214.

Hawkes CV, Sullivan JJ 2001. The impact of herbivory on plants in different resource conditions: a meta-analysis. Ecology 82: 2045-2058.

Huarte R, Benech-Arnold, R. 2005. Incubation under fluctuating temperatures reduces mean base water potential for seed germination in several non-cultivated species. Seed Science Research 15: 89-97.

Paynter Q, Fowler SV, Gourlay AH, Peterson PG, Smith LA, Winks CJ 2015. Relative performance on test and target plants in laboratory tests predicts the risk of nontarget attack in the field for arthropod weed biocontrol agents. Biological Control 80: 133142.

Pons TL 1984. Possible significance of changes in the light requirement of Cirsium palustre seeds after dispersal in ash coppice. Plant, Cell \& Environment 7: 263-268.

Schröder D 1980. The biological control of thistles. Biocontrol News and Information 1: 9-26.

Shea K, Kelly D 1998. Estimating biocontrol agent impact with matrix models: Carduus nutans in New Zealand. Ecological Applications 8: 824-832.

Shea K, Sheppard A, Woodburn T 2006. Seasonal life-history models for the integrated management of the invasive weed nodding thistle Carduus nutans in Australia. Journal of Applied Ecology 43: 517-526.

Sheppard AW 1996. The Interaction between Natural Enemies and Interspecific Plant Competition in the Control of Invasive Pasture Weeds. Proceedings of the IX International Symposium on Biological Control of Weeds. Pp. 47-53.

van Leeuwen $\mathrm{BH}$ 1981. The role of pollination in the population biology of the monocarpic species Cirsium palustre and Cirsium vulgare. Oecologia 51: 28-32.

Webb CJ, Sykes WR, Garnock-Jones PJ 1988. Flora of New Zealand. DSIR, Botany Division, Christchurch, New Zealand.

Winston R, Schwarzländer M, Hinz HL, Day M, Cock M, Julien M 2014. Biological Control of Weeds: A World Catalogue of Agents and Their Target Weeds. USDA Forest Service, Morgantown, West Virginia, USA. 